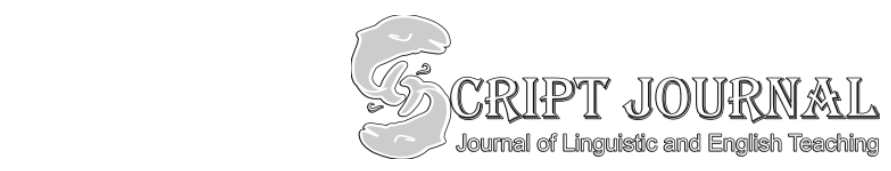

http://jurnal.fkip-uwgm.ac.id/index.php/Script

Script Journal: Journal of Linguistic and English Teaching

P-ISSN: 2477-1880; E-ISSN: 2502-6623

October 2017, Vol. 2 No. 2

Received: August 2107

Accepted: September 2017

Published: October 2017

Article DOI: http://dx.doi.org/10.24903/sj.v2i2.122

\title{
The Implementation of Aptitude Treatment Interaction (ATI) to Improve Learning Motivation of Low Achievement Students
}

\author{
Syawal \\ English Education Program, Muhammadiyah University of Parepare \\ awal.umpar@gmail.com/syawal_pbi@umpar.ac.id \\ Patahuddin \\ English Education Program, Muhammadiyah University of Parepare \\ elbazthakim@gmail.com
}

\author{
Alimuddin \\ Junior High School 6 Parepare, Jl. Pendidikan, Bukit Harapan, Soreang, Kota Parepare \\ rimba43@rocket.mail.com.
}

\begin{abstract}
This research was classroom action research, which aims at improving students' motivation of their poor performance through learning model Aptitude Treatment Interaction (ATI) on VII.3 grade students of SMP Negeri 6 Parepare. Aptitude Treatment Interaction (ATI) can serve individual student differences by adjusting treatment or learning method with students' abilities. The use of this model was emphasizing to create small groups of students that have achievement alike. Students with have low academic achievement based on test results and teacher interview will be grouped into one group and will be given preferential treatment by tutoring intensity rather than the group of high academic achievement. Subjects of this research were students of class VII.3 SMP Negeri 6 Parepare which is consist of 25 students. This research was conducted in two cycles. The procedure of this research involved four phases: (1) planning, (2) Implementation of action, (3) observation, (4) Reflection. The data collection was done by observation, tests, and questionnaires for each cycle after giving treatment through learning model Aptitude Treatment Interaction (ATI). Data collected were analyzed using quantitative and qualitative analysis. The results of this research indicate that the Aptitude Treatment Interaction (ATI) can be an alternative method to improve learning motivation of low achievement students. The results of this research also showed that the Aptitude Treatment Interaction (ATI) can be an alternative to problem-solving in the classroom, especially for low achievement students.
\end{abstract}

Keywords: Aptitude Treatment Interaction (ATI), Learning Motivation, and Low students' achievement 


\section{INTRODUCTION}

Language plays very vital role in the intellectual, social, and emotional development of learners as well as supporting their success in studying all areas of study (Bucholtz \& Hall, 2003; P. G. Hingne, 2013). Moreover, language learning is expected to help learners to know themselves, the culture, and other people's culture (Choudhury, 2014; Elmes, 2013). In addition, Méndez López \& Peña Aguilar (2013); Sirbu (2015) states that language learning also helps learners expressing their ideas and feelings, taking part in social interaction, and even discover and use the analytical and imaginative abilities that exist within him. Considering that fact, the language proficiency of language learners can become parameters to predict their success in studying. Nowadays, a language which is the most widely spread is English, therefore, mastering English will easily help learners to dig into the world of science.

As a global language, English is a tool of communication orally and written (Brydon, 2010; Poonam G. Hingne, 2013). Meanwhile, communicating is understanding and disclosing information, thoughts, feelings, and developing science, technology, and culture (Lebow, 2008; Sariakin, 2016). The ability to communicate in the full sense is the ability to discourse, i.e. the ability to understand and/or produce oral and/or written text that is realized in four language skills, namely listening, speaking, reading and writing. These four skills are used to respond or create a discourse in social life. Therefore, English subjects are directed to develop these skills so that graduates are able to communicate and discourse in English at a certain literacy level (Katombe, 1993).

Literacy levels consider being the guideline in determining the target of learning English in every level of schools in Indonesia. Levels of literacy involve performative, functional, informational, and epistemic. At a performative level, people are able to read, write, listen, and talk to the symbols used. At a functional level, people are able to use language to meet the needs of daily living such as reading newspapers, manuals or hints. At the informational level, people able to access knowledge with language skills, while at the epistemic level one is able to express knowledge into the target language (Wells, 1987). Learning English in Junior High School / MTs is targeted that learners can reach the functional level where the learners are expected to be able to communicate orally and written. On the contrary, students of Senior High School or SMA / MA is expected to reach the informational level, where they will face more complex and larger source of information as a bridge to continue their education to university levels. Moreover, English serves as a Foreign 
language in Indonesia effects on the ignorance of Epistemic literacy as it considered too high to be achieved by high school / MA students.

Regarding to the important of literacy levels which addressed functional level for the students in Junior high school, Gillies \& Boyle (2010); R. Slavin (2011); R. E. Slavin et al., (1985) states that cooperative learning model is considered as one of the learning models that are available to maintain the learning process because this learning model prioritizes cooperation among students to achieve learning objectives. In addition, Furtwengler (1992); Gillies (2003); Johnson \& Johnson (1999); Smith (1995) argue that groups are formed from students with different academic abilities in order that students can develop social skills such as sharing duties, actively ask questions, appreciate the opinions of others and work in groups. Although the concept of cooperative learning model seems brilliant, in fact, the implementation of the learning model has not been able to improve low-ability students' learning outcomes because mostly the group is dominated high ability students. Baines, Blatchford, \& Webster (2014); Johnson \& Johnson (1984); Thanh \& Gillies (2010) identifies the main obstacles in cooperative learning: During class discussions, sometimes dominated by one student who considers himself the most capable, this leads the other students to become passive. In addition, Davidson \& Major (2014) assume that mostly this group tends to ignore the group of friends who are considered less capable which resulting in the low motivation of low-ability students in learning.

This research objective due to the result of observation and interviews to the teachers at SMP Negeri 6 Parepare which prove that teachers are difficult to maintain group formation. The problem refers to the domination of high-ability students to low-ability students, even, those categorize moderate-ability students tend to be passive in the classroom. As the result, students who have the low ability obtain average learning outcomes under standardized score (KKM) that only reaches 45.60 while the target standardized score should be 70.00. Addressing the problem appears, the researchers assume that this circumstance requires a learning method that does not neglect the low-ability students. Firstly, the researcher assumes that low-ability students as an effect of low motivation in learning English as Bernaus (1995); Ushida (2005) state that motivation is a process that gives spirit, direction, and persistence behavior. Moreover, Al-Tamimi \& Shuib (2009; Bernaus (1995); Gorges \& Kandler (2012); Rifai (2010); Shaikholeslami \& Khayyer (2006); Ushida (2005) assume that learning motivation refers to the driving force from within themselves to perform certain activities to achieve a goal. In addition, Aarts, Gollwitzer, \& Hassin (2004); Elliott \& Dweck (1988); Lunenburg (2011) promote that motivation is a 
change of energy in a person characterized by the emergence of "feeling" and preceded by a response to the existence of a goal.

Pursuing the target of serving learners with high learning motivation, it could be proposed that motivation is the overall driving force within the student that raises, ensures continuity, and that gives direction in learning activities. So the expected goal can be achieved with good and maximum effort. Motivation to learn is the overall driving force belongs to the learners which encourage, stabilize, and direct performance of activities on learning activities as a result of leraning experience to achieve a goal (needs) and obtain a change of behavior. Motivation can also be called a passionate grower, feel happy, and a passion for learning. With strong motivation, students will have a lot of energy to do learning activities and achieve high achievement. Shortly, motivation greatly affects the success of student learning to achieve a goal. Motivation to learn is not enough yet without the motivation of the surroundings either from teachers, peers, and learning goals which can affect the success of students to get a good and satisfactory learning achievement.

To achieve goals of learning language, motivation is not enough yet. Enhancing motivation to learn should be in line with good learning approach. Once is Aptitude Treatment Interaction (ATI) learning model which is assumed to be available as a short cut to encourage learners motivation. Kanfer \& Ackerman (1989); Linden (2004); Reynolds (1988); Snow (1989a), (1991) states that ATI is a learning model that has effective learning strategies used for specific individuals in accordance with their respective abilities. ATI is a learning model that can serve individual differences of students that are to adjust the treatment or learning methods with the ability of students. Etymologically, ATI consist of three words involves; aptitude means intelligence or ability; treatment refers to an action given to the learners, and interaction refers to learners communication during the learning process. Moreover, Aptitude Treatment Interaction (ATI) is an approach that seeks to find and find treatments that match the aptitude of students' abilities, i.e. optimal treatments applied to students of different levels of ability Goska \& Ackerman (1996); Kieft, Rijlaarsdam, \& van den Bergh (2008); Seufert, Schutze, \& Brunken (2009). In addition, Hwu, Pan, \& Sun (2014) suggests that in the Aptitude Treatment Interaction (ATI) involves several steps: 1) ability test, 2) grouping students, 3) preliminary test, 4) giving treatment and 5) Achievement test. 


\section{METHODOLOGY}

This research was classroom action research which consists of 4 stages involves planning, action, observation, and reflection. This study was conducted in SMP Negeri 6 Parepare, South Sulawesi. The subject of this research was the students of class VII.3 SMP Negeri 6 Parepare in 2015/2016 academic year. The data was obtained from students and subject teachers. The types of data obtained were collected in the following through; data on students learning outcomes was obtained from learning outcomes in each cycle which were collected by using test techniques; data on students learning activities obtained through the observation sheet, collected using observation techniques; and data on students learning motivation is obtained through questionnaire of learning motivation.

To obtain the data, the researchers used the instruments in the form of test which is used to obtain students learning outcomes. This test is in the form of description and prepared on the basis of established indicators. Moreover, to obtain the data about the group learning condition, the researchers used observation sheet to measure how the interaction of students' group going on. This was applied on every learning cycle. And the last was a questionnaire, it was used to obtain the data about students' learning motivation. This method is implemented after the implementation of the cycle I and Cycle II.

\section{FINDINGS}

The results of the research regarding learners motivation in cycle I of students at class VII.1 SMP Negeri 6 Parepare showed that the average score of learners' learning motivation is equal to 2.96 with a standard deviation of 0.25 . The lowest score achieved was 2.55 and the highest score was 3.25 from the ideal score of 5.00. Moreover, the data shows that all the students' motivation is in "enough category". However, learners motivation in cycle II is equal to 3,87 with standard deviation 0,45. The lowest score achieved was 3.05 and the highest score was 4.40 from the ideal score of 5.00. Furthermore, it was found that $75 \%$ students have "good" motivation toward learning English while the rest $25 \%$ students were in "enough" category. In addition, the average score of English learning motivation in the second cycle is 3.87, the data reveals that students' learning motivation at SMP Negeri 6 Parepare both in cycle I and cycle II were improved from "enough" category to "good" category. The analysis of English learning motivation per indicators in both cycle I \& II reveals that five measure's indicators involve attention, interest, happiness, curiosity, and mood were improved in cycle II (see chart 1. Average learning motivation of each indicators on cycle I and cycle II). 


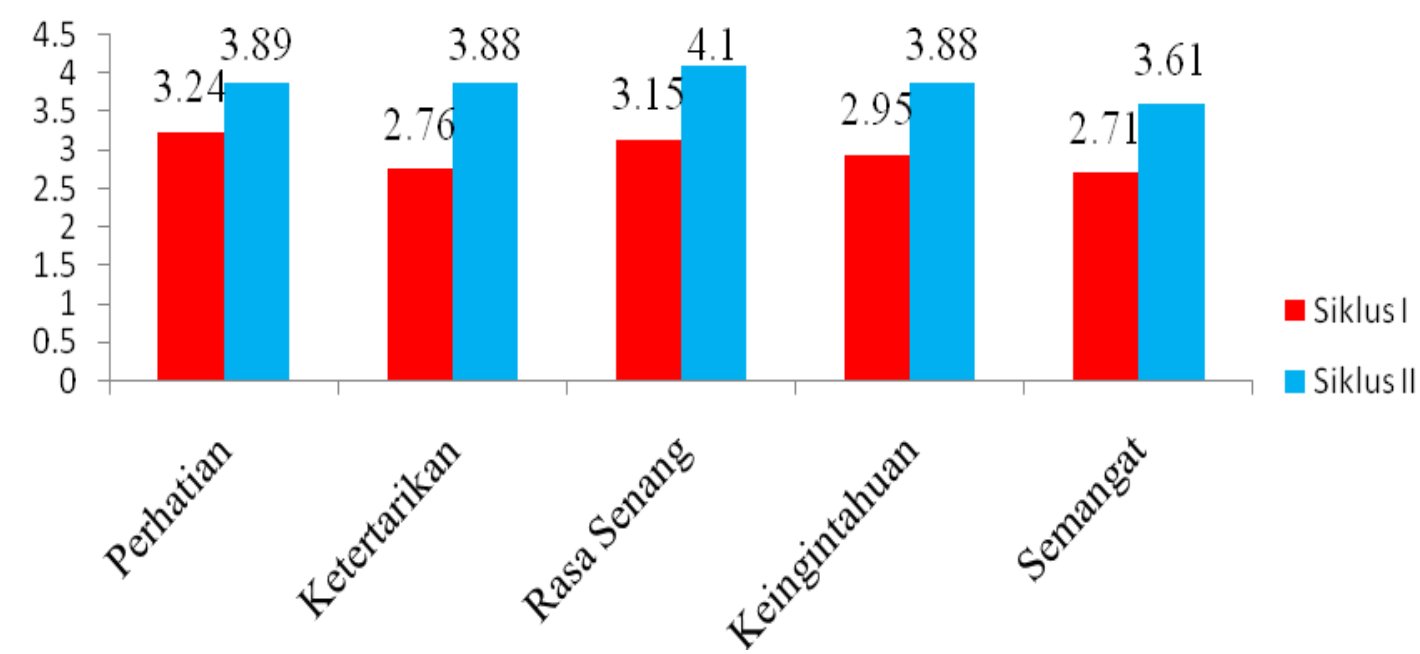

Chart 1. Average learning motivation of each indicator on cycle I and cycle II

Another finding of this research refer to the students' activities during the learning process in both cycles I and cycle II. Learners' activities which were observed regarding all students' activities in learning English through Aptitude Treatment Interaction (ATI) which is limited to; students' attendance; students' attention to teachers' explanation; students' answer; questioning and doing exercise. The data shows that the students' attendance improves from $91.66 \%$ in cycle I became $95.00 \%$ in cycle II. Moreover, students' attention to teachers' explanation arose from $70.44 \%$ in cycle I to $89.63 \%$ in cycle II. Furthermore, regarding question coming from teachers, the data shows that in cycle $\mathrm{I}$, the percentage of students who answer the teachers' question is $67.89 \%$ on the contrary, it becomes $87.40 \%$ in cycle II. In addition, percentage of students' question reveals that the difference between cycle I and cycle II only about $26.68 \%$ in cycle I and $28.21 \%$ in cycle II. Finally, the significant improvement could be seen in the percentage of students in doing an exercise where in cycle I am about $75.04 \%$ while in cycle II it improves up to $94.81 \%$. (see chart 2. Comparison of Students' Activity percentage from cycle I to cycle II). 


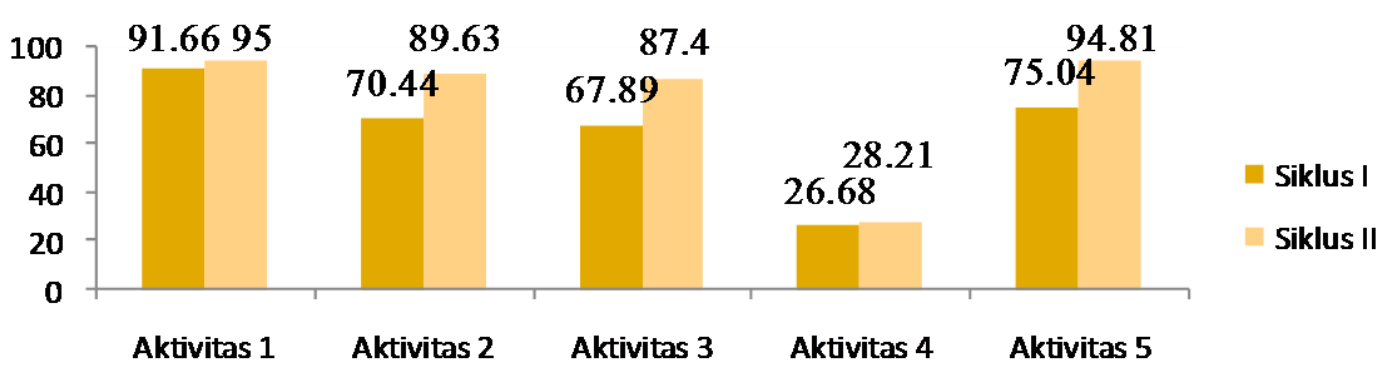

Chart 2. Comparison of Students' Activity percentage from cycle I to cycle II).

Observation on teachers' competence in manage classroom through Aptitude Treatment Interaction (ATI) was observed in every meeting both in cycle I and cycle II. Based on the observation, the data reveals that the teachers' competence improves from cycle I to cycle II. The improvement was categorized very well based on rubrics proposed by Sutomo.

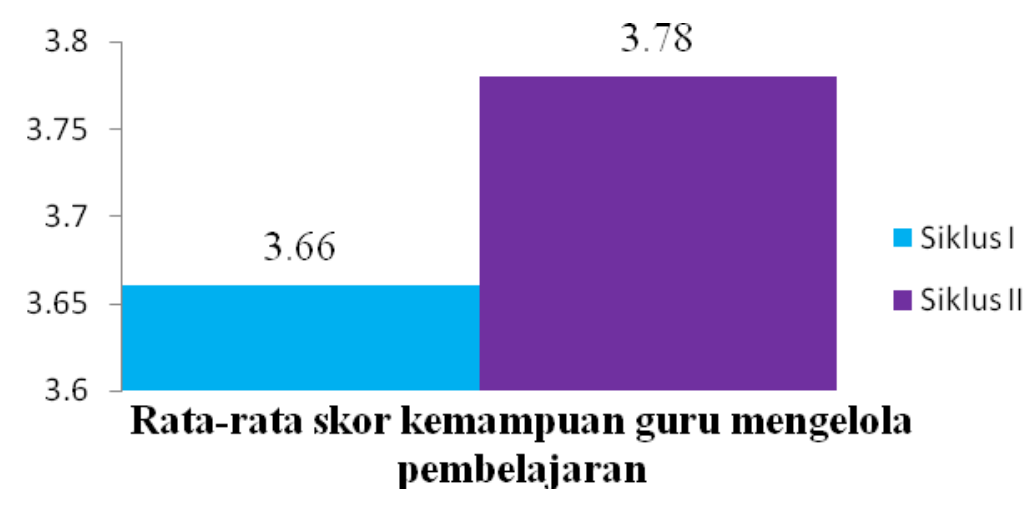

Chart 3. Average scores of teachers ability in maintaining group study in Cycle I and Cycle II

\section{DISCUSSION}

Observation result of students' motivation reveals that students who have low motivation score get less satisfactory score toward English communication ability while learners who have higher motivation level get a better score. Furthermore, through the Aptitude Treatment Interaction Approach, English learning becomes more fun, meaningful, and involves the senses of learners optimally. Therefore, learners become more interested in following the learning process that ultimately increases the motivation of learners. These results indicate that the Aptitude Treatment Interaction Approach significantly effective to improve students learning motivation as well as enhance students activity in achieves English learning.

The learning process of learners mostly refers to their motivation. The higher their motivation is, the more conceited their learning process and vice versa. As stated by 
Kusurkar, Ten Cate, Vos, Westers, \& Croiset (2013) who stated that Relative Autonomous Motivation which is the balance of Autonomous Motivation (AM) and Controlled Motivation (CM) positively correspondent to learning performance. Those, it is very recommended that in teaching and learning process, the teacher should always maintain the learner's motivation instead the motivation will decrease.

Considering the result of observation, the data reveals that the implementation of Aptitude Treatment Interaction Approach gives good impact on students learning activity. Furthermore, most students seem enthusiastic in attending the class as well as give attention to the teacher explanation before group studies started especially in cycle II. In addition, Aptitude Treatment Interaction Approach serves the students with the treatment given are suitable for their needs which endorse their curiosity. Regarding treatment given to the students, the effectiveness of interaction through group discussion lead the students to interact freely without feeling hesitate. This fact is in line with the previous expert Snow (1989b) assumption that the better the learning treatment that is applied with the difference of students' ability, hence the more optimal student learning outcomes.

By the virtue of the fact gained from this research, some possibilities beyond the preassumption of Aptitude Treatment Interaction Approach implementation involves; Aptitude Treatment Interaction Approach gives more opportunity for both teachers and students to interact. These situations lead to the smoothness of learning process. Furthermore, students will be more active in presenting their idea as well as giving and answering the question; Moreover, through group discussion, the students will feel free to utter their idea and sharing an opinion as well.

\section{CONCLUSION}

Without encouraging the result of the research, It's very clear from the above discussion that Aptitude Treatment Interaction Approach and motivation are intricately interwoven so that one cannot separate the two without losing the significance of either approach or motivation. If any one of them is separated the other remains incomplete. In learning English, the students should have high motivation with appropriate teaching and learning approach so that the students can acquire the learning material and apply it in their life situations. It is observed that many teaching approaches which is very difficult to correspond with the students learning motivations. Therefore, the role of an approach that it plays in teaching and learning of English should go along with the importance of endorsing students motivation. The teacher periodically evaluates the teaching competence as well as 
trying to improve his ability through workshop and further education in accordance with his duties and responsibilities. Teachers also must always try to improve the quality of learning by improving the management of learning. The teachers are expected to pay attention to the relevance the teaching approach and students' motivation. Furthermore, further research is expected to fulfill the development of learning experiences and recent life skills in improving the quality of learning outcomes. This is important to ensure learning process of acquiring English as a Foreign language in Indonesia to be better in the future which results in better quality of learners and reliable to compete in the universe. 


\section{BIBLIOGRAPHY}

Aarts, H., Gollwitzer, P. M., \& Hassin, R. R. (2004). Goal Contagion: Perceiving Is for Pursuing. Journal of Personality and Social Psychology, 87(1), 23-37. https://doi.org/10.1037/0022-3514.87.1.23

Al-Tamimi, A., \& Shuib, M. (2009). Motivation and attitudes towards learning English: A study of petroleum engineering undergraduates at Hadhramout University of Sciences and Technology. GEMA Online Journal of Language Studies, 9(2), 29-55.

Baines, E., Blatchford, P., \& Webster, R. (2014). The challenges of implementing group work in primary school classrooms and including pupils with special educational needs. Education 3-13, 43(1), 15-29. https://doi.org/10.1080/03004279.2015.961689

Bernaus, M. (1995). The role of motivation in the learning of English as a foreign language. BELLS : Barcelona English Language and Literature Studies, 6, 0011-0021.

Brydon, D. (2010). Critical literacies for globalizing times. Critical Literacies: Theories and Practices, 4(2), 16-28.

Bucholtz, M., \& Hall, K. (2003). Language and Identity. In A Companion to Linguistic Anthropology (pp. 637-657). Oxford: Basil Blackwell.

Choudhury, R. U. (2014). THE ROLE OF CULTURE IN TEACHING AND LEARNING OF ENGLISH. An International Journal of Multi Disciplinary Research, 1(4), 1-20.

Davidson, N., \& Major, C. H. (2014). Boundary Crossings: Cooperative Learning, Collaborative Learning, and Problem-Based Learning. Journal on Excellence in College Teaching, 25(3\&4), 7-55.

Elliott, E. S., \& Dweck, C. S. (1988). Goals: An approach to motivation and achievement. Journal of Personality and Social Psychology, 54(1), 5-12. https://doi.org/10.1037/0022-3514.54.1.5

Elmes, D. (2013). The relationship between language and culture. 鹿屋体育大学学術研究紀要, 46, 11-17. https://doi.org/10.1111/j.14679280.2009.02412.x

Furtwengler, C. B. (1992). How to Observe Cooperative Learning Classrooms. Educational Leadership, 49(7), 59-62.

Gillies, R. M. (2003). Structuring cooperative group work in classrooms. International Journal of Educational Research, 39(1-2), 35-49. https://doi.org/10.1016/S08830355(03)00072-7

Gillies, R. M., \& Boyle, M. (2010). Teachers' reflections on cooperative learning: Issues of 
implementation. Teaching and Teacher Education, 26(4), 933-940. https://doi.org/10.1016/j.tate.2009.10.034

Gorges, J., \& Kandler, C. (2012). Adults' learning motivation: Expectancy of success, value, and the role of affective memories. Learning and Individual Differences, 22(5), 610617. https://doi.org/10.1016/j.lindif.2011.09.016

Goska, R. E., \& Ackerman, P. L. (1996). An aptitude-treatment interaction approach to transfer within training. Journal of Educational Psychology, 88(2), 249-259. https://doi.org/10.1037/0022-0663.88.2.249

Hingne, P. G. (2013). Impressive Tool to Communicate in Modern World is the Language English. International Journal of Social Science and Humanity, 3(3), 319-321. https://doi.org/https://doi.org/10.7763/IJSSH.2013.V3.253

Hingne, P. G. (2013). Impressive Tool to Communicate in Modern World is the Language English. International Journal of Social Science and Humanity, 3(3), 319-321. https://doi.org/10.7763/IJSSH.2013.V3.253

Hwu, F., Pan, W., \& Sun, S. (2014). Aptitude-treatment interaction effects on explicit rule learning: A latent growth curve analysis. Language Teaching Research, 18(3), 294-319. https://doi.org/https://doi.org/10.1177/1362168813510381

Johnson, D. W., \& Johnson, R. T. (1984). Cooperative Small-Group Learning. National Association of Secondary School Principals, 14(1).

Johnson, D. W., \& Johnson, R. T. (1999). Making cooperative learning work. Theory Into Practice, 38(2), 67-73. https://doi.org/10.1080/00405849909543834

Kanfer, R., \& Ackerman, P. L. (1989). Motivation and cognitive abilities: An integrative/aptitude-treatment interaction approach to skill acquisition. Journal of Applied Psychology, 74(4), 657-690. https://doi.org/10.1037/0021-9010.74.4.657

Katombe, D. (1993). Development and transfer in reading ability : a study of Zairean EFL learners.

Kieft, M., Rijlaarsdam, G., \& van den Bergh, H. (2008). An aptitude-treatment interaction approach to writing-to-learn. Learning and Instruction, 18(4), 379-390. https://doi.org/https://doi.org/10.1016/j.learninstruc.2007.07.004

Kusurkar, R. A., Ten Cate, T. J., Vos, C. M. P., Westers, P., \& Croiset, G. (2013). How motivation affects academic performance: a structural equation modeling analysis. Advances in Health Sciences Education, 18(1), 57-69. https://doi.org/https://doi.org/10.1007/s10459-012-9354-3

Lebow, R. N. (2008). Identity and International Relations. International Relations, 22(4), 
473-492. https://doi.org/https://doi.org/10.1177/0047117808097312

Linden, V. Der. (2004). aptitude treatment interaction. Psychometrika, 69, 355-374.

Lunenburg, F. C. (2011). Goal-Setting Theory of Motivation. International Journal of Management, Business, and Administration, 15(1), 1-6.

Méndez López, M. G., \& Peña Aguilar, A. (2013). Emotions as Learning Enhancers of Foreign Language Learning Motivation. Profile: Issues in Teachers' Professional Development, 15(1), 109-124.

Reynolds, C. R. (1988). Putting the individual into aptitude-treatment interaction. Exceptional Children, 54(4), 324-331. https://doi.org/10.1177/001440298805400406

Rifai, N. Al. (2010). Attitude, motivation, and difficulties involved in learning the English language and factors that affect motivation in learning it. In Procedia - Social and Behavioral Sciences (Vol. 2, pp. 5216-5227). https://doi.org/10.1016/j.sbspro.2010.03.849

Sariakin, S. (2016). Model-Based Development of English Language Learning Characters in Improving Students Achievement of Sma. Jurnal Ilmiah Peuradeun, 4(2), 173-182. https://doi.org/10.13140/RG.2.1.2699.9921

Seufert, T., Sch??tze, M., \& Br??nken, R. (2009). Memory characteristics and modality in multimedia learning: An aptitude-treatment-interaction study. Learning and Instruction, 19(1), 28-42. https://doi.org/10.1016/j.learninstruc.2008.01.002

Shaikholeslami, R., \& Khayyer, M. (2006). Intrinsic motivation, extrinsic motivation, and learning English as a foreign language. Psychological Reports, 99(3), 813-818. https://doi.org/10.2466/PR0.99.3.813-818

Sirbu, A. (2015). the Significance of Language As a Tool of Communication. Naval Academy Scientific Bulletin, XVIII(2), 2-3.

Slavin, R. (2011). Instruction based on cooperative learning. Handbook of Research on Learning and Instruction, 344-360.

Slavin, R. E., Sharan, S., Kagan, S., Lazarowitz, R. H., Webb, C., \& Schmuck, R. (1985). LEARNING TO COOPERATE, COOPERATING TO LEARN - SLAVIN,RE. Teachers College Record. https://doi.org/10.1007/978-1-4899-3650-9

Smith, K. A. (1995). Cooperative learning: effective teamwork for engineering classrooms. In Proceedings Frontiers in Education 1995 25th Annual Conference. Engineering Education for the 21st Century, 1(December 1995), 2b5.13-2b5.18. https://doi.org/https://doi.org/10.1109/FIE.1995.483059

Snow, R. E. (1989a). Aptitude-treatment interaction as a framework for research on Copyright @ 2017, Script Journal: Journal of Linguistic and English Teaching,p-ISSN 2477-1880, e-ISSN $2502-6623$ 
individual differences in learning. In Learning and individual differences: Advances in theory and research (pp. 13-59).

Snow, R. E. (1989b). Aptitude, instruction, and individual development. International Journal of Educational Research, 13(8), 869-881. https://doi.org/10.1016/08830355(89)90070-0

Snow, R. E. (1991). Aptitude-treatment interaction as a framework for research on individual differences in psychotherapy. Journal of Consulting and Clinical Psychology, 59(2), 205-216. https://doi.org/10.1037/0022-006X.59.2.205

Thanh, P. T. H., \& Gillies, R. (2010). Group Composition of Cooperative Learning: Does Heterogeneous Grouping Work in Asian Classrooms? International Education Studies, 3(3), 12-19. https://doi.org/10.5539/ies.v3n3p12

Ushida, E. (2005). The role of students' attitudes and motivation in Second Language Learning in online language courses. CALICO Journal, 23(1), 49-78. https://doi.org/10.1111/j.1467-1770.1956.tb01198.x 